\title{
Analisa Infrastruktur Desa Sukaci-Baros Dengan Metode Critical Path Method (CPM)
}

\author{
Ahmad Nalhadi ${ }^{1}$ dan Nana Suntana ${ }^{2}$ \\ Program Studi Teknik Industri, Fakultas Teknik, Universitas Serang Raya \\ irqi02@gmail.com ${ }^{1}$, nanasuntana46@gmail.com²
}

\begin{abstract}
Abstrak -- CV. ABP sebuah perusahaan kontruksi yang bergerak di bidang pengembangan bangunan infrastruktur bangunan swasta dan pemerintah. Saat ini CV. ABP sedang menangani proyek pembangunan infrastruktur kawasan agropolitan (Rigit Payement) Desa Sukaci - Baros. Proyek tersebut mengalami keterlambatan selama 19 hari dari waktu yang di tentukan yaitu 126 hari, sehingga mengalami pembengkakan biaya, karena menejemen perusahaan yang kurang baik menjadi akar permasalahannya. Untuk mengembalikan waktu proyek dibutuhkan penekanan waktu dan biaya dari rencana yang telah ditentukan, maka akan dilakukan evaluasi penjadwalan menggunakan metode Critical Path Method (CPM) dan melakukan Crashing untuk mencari hasil yang optimal. Dengan menggunakan Critical Path Method (CPM) didapatkan pekerjaan yang berada dilintasan kritis, diantaranya : Gali Tanah, Pemasangan Boflang, Pemasangan Batu Belah, Perataan Agregat B, Perataan Agregat A, Pekerjaan Rigit Bavement, dan Pembesian, jika dilakukan penekanan waktu dihasilkan waktu yang optimal dari 126 hari menjadi 92 hari. Alternatif yang di ambil yaitu alternatif penambahan jam kerja dengan durasi 92 hari. Setelah dilakukan crashing. menggunakan 2 alternatif, penambahan jam kerja dan penambahan tenaga kerja, didapatkan selisih penambahan jam kerja yaitu $R p$ 80.128.125 dan penambahan tenaga kerja $R p$ 55.260.000 dari biaya normal.
\end{abstract}

Kata kunci: Crashing; Critical Path Method; dan Manajemen Proyek

Abstract -- CV. ABP a construction company worked in infrastructure building development for private and goverment. Now CV. ABP is handling infrastructure development project of the acropolitan area (Right Payment) Sukaci - Baros Village. This project has been late for 19 days from the dead line 126 days. Therefore the cost is getting higher. It's happened because bad management is the problem source. Restoring the project time need to be focused on the cost and the due date based on the schedule. Scheduling evaluation using Critical Path Method (CPM) and Crashing to find optimal results using Critical Path Method (CPM) can be found the critical paths activity, there are ground digging, bopflang installation, stone installation, agregrate $B$ agrgregation , aggregate $A$ flatting, rigit bavement work, and refining, when the time suppression obtained optimal time results from 126 days to 92 days. It taken an alternative to the addition of working hours with duration 92 day after the crashing. Using two alternatives, additional working hours and the addition of workforce, obtaining the difference of extra hours of work cost Rp 80.128.125 and labourcost increase $\mathrm{Rp} 55.260$ from the regular cost.

Keywords: Crashing; Critical Path Method; and Project Management

\section{PENDAHULUAN}

Saat ini persaingan yang terjadi dalam dunia konstruksi menjadi lebih ketat dan kompetitif apabila dibandingkan dengan persaingan di masa lalu. Keadaan ini menyebabkan terjadinya kompetisi dari segi biaya, waktu, dan kualitas pekerjaan yang ditawarkan oleh perusahaan konstruksi untuk memenangkan hak pekerjaan dari suatu proyek, sehingga memicu terjadinya perang harga dan waktu pekerjaan proyek yang terjadi dalam masa penawaran proyek yang dilakukan oleh owner.

Demi kelancaran sebuah proyek dibutuhkan manajemen yang akan mengelola proyek dari awal hingga akhir, yakni manajemen proyek. Menurut Aribowo, Fatkhurokhman, \& Hamid (2016) manajemen proyek merupakan suatu metode yang menawarkan pengelolaan proyek dengan biaya yang minimal, waktu yang tepat dan mutu yang telah ditetapkan dalam perencanaan proyek. Keberhasilan atau kegagalan dari pelaksanaan proyek sering terjadi karena kurang terencananya kegiatan 
proyek dan pengendalian yang kurang efektif, menjadikan kegiatan proyek tidak efisien.Hal ini menyebabkan keterlambatan waktu, menurunnya kualitas pekerjaan, dan membengkaknya biaya pelaksanaan.

CV. ABP merupakan perusahaan kontruksi yang menangani beberapa proyek pembangunan infrastuktur jalan, jembatan, gedung, dan lain-lain. Di dalam melaksanakan proyek tersebut sering mengalami keterlambatan yang tidak sesuai dengan rencana. Penyebab yang paling dominan adalah kurangnya manajemen perusahaan dalam pengendalian pelaksanaan proyek sehingga tidak efektif, dan kegiatan proyek tidak efisien, tidak sesuai dengan jadwal yang ditentukan, sehingga terjadinya penambahan waktu dan biaya. Untuk mengestimasi waktu serta biaya dalam sebuah proyek maka diperlukan penekanan waktu serta biaya. Penekanan waktu dan biaya biasanya dilakukan untuk mengoptimalkan sumber daya yang ada, serta meminimalkan kendala namun tetap mendapatkan hasil yang optimal.

Salah satu metode yang dapat digunakan untuk mengoptimalkan pengerjaan proyek adalah Critical Path Method (CPM). CPM adalah analisa jaringan kerja yang bertujuan mengoptimalkan biaya proyek melalui pengurangan atau percepatan durasi penyelesaian proyek (Satria, \& Pandy, 2016). Penggunaan CPM diasumsikan jumlah waktu pengerjaan proyek, hubungan antara sumber yang digunakan dan waktu yang diperlukan dalam pengerjaan proyek dianggap diketahui dengan pasti.

Pengunaan metode CPM mampu mempercepat penyelesaian proyek yang mulanya selama 217 hari kalender menjadi 210 hari kalender pada proyek kontruksi jalan (Handayani \& Dedy Iskandar, 2015). Penelitian yang dilakukan Munang, Faisal, \& Mansur (2016) didapatkan bahwa percepatan pekerjaan proyek dapat menghemat biaya sebesar Rp730.638.742. Priyo \& Aulia (2015) menyatakan biaya percepatan durasi proyek (penambahan tenaga kerja atau jam lembur) lebih murah dibandingkan degan biaya yang dikeluarkan apabila proyek mengalami keterlambatan dan dikenakan denda. Biaya mempercepat durasi proyek

Penelitian ini berusaha mengoptimalkan pengerjaan proyek dengan menggunakan CPM karena metode ini mampu mengoptimalkan pengerjaan proyek dari sisi biaya dan keuntungan. Selain itu CPM dapat digunakan sebagai bahan evaluasi ketika pekerjaan berlangsung, sampai dengan ketika terdapat kendala-kendala didalam melaksanakan proyek tersebut. Penelitian ini bertujuan mengetahui pekerjaan yang termasuk kedalam kegiatan lintas kritis, durasi proyek pembangunan Infrastruktur, dan penghematan biaya pengerjaan proyek.

\section{METODOLOGI PENELITIAN}

Penelitian ini dilakukan pada perusahaan yang bergerak dibidang proyek infrastuktur jalan, jembatan, gedung dan lain-lain. Pengumpulan data yang diperlukan berupa pengumpulan data teoritis dan data historis. Data teoritis berupa teori tentang manajemen proyek, Pehitungan EET (Earliest Event Time), Perhitungan LET (Latest Event Time,dan . Penundaan (Float).. Data historis yang diperlukan adalah data variabel, yaitu data kuantitatif Gantt Chart, Network diagram dan Schedule.

\section{Gant Chart}

Gantt Chart merupakan sejenis grafik batang yang digunakan untuk menunjukkan tugas proyek, jadwal dab waktu pelaksanaannya, seperti waktu dimulainya proyek dan batas waktu yang digunakan untuk menyelesaikan proyek. Hardiyanta (2015) menyatakan Gantt chart digunakan untuk mengidentifikasikan unsur waktu tiap kegiatan, dari awal sampai akhir proyek. Tiap-tiap garis menunjukkan awal kegiatan sampai dengan akhir waktu penyelesaian kegiatan dan serangkaian kegiatan yang ada disuatu proyek

Langkah - langkah dalam membuat Gantt Chart serta cara penggunaannya.

1. Mengidentifikasikan tugas yang diselesaikan pada proyek

2. Menentukan bagian pekerjaan dari proyek (Milestone) dengan Brainstorming atau Flow chart.

3. Mengidentifikasikan waktu yang diperlukan dalam menyelesaikan proyek.

4. Mengidentifikasikan urutan pekerjaan atau tugas yang akan dikerjakan.

5. Menggambarkan Sumbu Horizontal

6. Menuliskan bagian pekerjaan

7. Melakukan pemeriksaan kembali

\section{Critical Path Method (CPM)}

CPM pada dasarnya adalah merupakan metode yang berorientasi pada waktu, dalam arti bahwa CPM akan berakhir pada penentuan waktu. Metode ini mengidentifikasi jalur kritis pada aktifitas yang ditentukan ketergantungan antar aktifitasnya. Aktifitas merupakan tugas spesifik yang mempunyai hasil yang dapat diukur dari durasi pengerjaannya (Rosanti, Setiawan, \& Ayuningtyas, 2016) Menurut Husen (2011) Jalur kritis adalah suatu deretan kegiatan 
kritis yang menentukan jangka waktu penyelesaian bagi keseluruhan proyek. Dapat diartikan bahwa jalur kritis merupakan rantai kegiatan kritis yang menghubungkan titik dimulainya dan diakhirinya kegiatan dalam anak panah atau dengan singkat dikatakan jalur kritis terdiri dari kegiatan - kegiatan yang kritis.

Penggambaran Critical Path Method menggunakan simbol yang dapat berbentuk segi empat atau lingkaran. Simbol-simbol ini dapat digunakan asal disertai legenda yang menjelaskan tentang apa yang dimaksud oleh pembuatnya. Di bawah ini adalah gambar contoh penggambaran CPM untuk satu item pekerjaan.

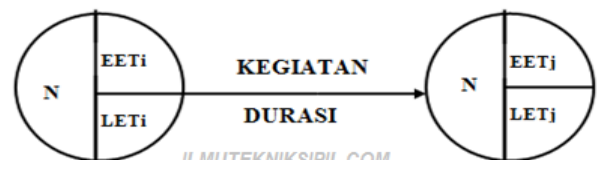

Gambar 1. Diagram CMP untuk satu item pekerjaan

\section{Keterangan :}

a. Lingkaran disebut juga node menunjukkan berawalnya suatu pekerjaan ataupun berakhirnya suatu pekerjaan

b. Garis panah (arrow) menunjukkan pekerjaan, arah panah ke suatu node menunjukkan urutan antar pekerjaan. Jika garisnya tebal berarti lintasan kritis (critical path). Jika garisnya putus-putus berarti pekerjaannya semu (dummy), secara alogika pekerjaan tersebut ada tetapi dalam kenyataannya tidak ada sehingga durasinya pun nol

c. EETi : (Earliest Event Time i) Saat paling awal pekerjaan dimulai

d. EETj : (Earliest Event Time j) Saat paling dini pekerjaan berakhir

e. LETi : (Latest Event Time i) Saat paling lambat pekerjaan dimulai

f. LETj : (Latest Event Time j) Saat paling lambat pekerjaan berakhir

g. Durasi : Lama pekerjaan berlangsung

h. $\mathrm{N}$ : Nomor pengidentifikasian node

Dalam penyusunan Critical Path Method, simbol-simbol di atas tersebut digunakan dengan mengikuti aturan-aturan sebagai berikut.

a. Setiap kegiatan diwakili oleh satu dan hanya satu anak panah dalam jaringan kerja, atau di antara dua pekerjaan yang sama hanya boleh digambarkan satu anak panah. Lihat gambar di bawah ini :

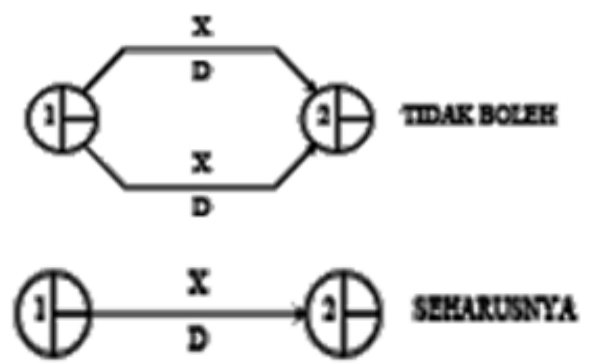

Gambar 2. Aturan Simbol CPM

b. Nama suatu kejadian dinyatakan dengan huruf atau dengan nomor pekerjaan. Setiap lingkaran pekerjaan diberi nomor sedemikian rupa, sehingga tidak terdapat lingkaran yang berulang kembali agar tidak terjadi circularity.

c. Kegiatan harus dimulai dari kejadian yang bernomor rendah ke kejadian bernomor tinggi.

\section{Pehitungan EET (Earliest Event Time)}

Untuk menghitung besarnya nilai EET digunakan perhitungan ke depan (Forwoard Analysis), dimulai dari kegiatan paling awal dan dilanjutkan dengan kegiatan berikutnya.

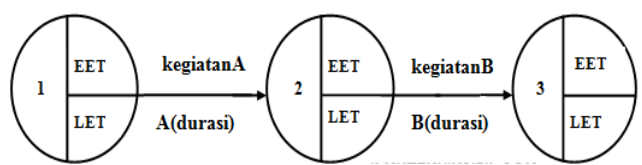

Gambar 3. Perhitunagn Earliest Event Time

$\mathrm{EET}_{2}=\mathrm{EET}_{1}+$ durasi $\mathrm{A}$
$\mathrm{EET}_{3}=\mathrm{EET}_{2}+$ durasi B

Apabila pada pehitungan EET pada suatu kegiatan terdapat hasil lebih dari satu maka dipilih yang paling besar.

\section{Perhitungan LET (Latest Event Time)}

Untuk menghitung besarnya nilai LET digunakan perhitungan kebelakang (Backward Analysis), dimulai dari kegiatan paling akhir dan dilanjutkan dengan kegiatan-kegiatan sebelumnya.

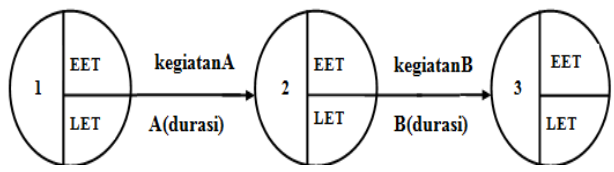

Gambar 4. Perhitungan Latest Event Time 


$$
\mathrm{LET}_{2}=\mathrm{LET}_{1}-\text { durasi } \mathrm{A}
$$$$
\operatorname{LET}_{3}=\mathrm{LET}_{2}-\text { durasi } \mathrm{B}
$$

Apabila pada pehitungan LET pada suatu kegiatan terdapat hasil lebih dari satu maka dipilih yang paling kecil.

\section{Penundaan (Float)}

Float (Penundaan) merupakan ukuran batas toleransi keterlambatan suatu aktivitas yang non kritis.

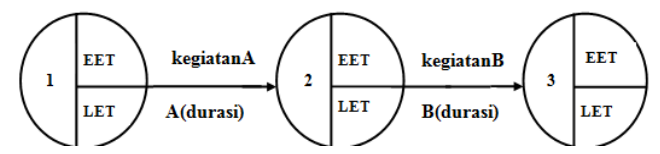

Gambar 5. Kegiatan Penundaan (Float)

Total Float (TF) merupakan jumlah penundaan maksimum yang dapat diberikan pada suatu kegiatan tanpa menghambat penyelesaian keseluruhan proyek. $\mathrm{TF}=\mathrm{LET}_{2}-\mathrm{EET}_{1}$ - durasi

(5)

$\mathrm{TF}=\mathrm{LET}_{3}-\mathrm{EET}_{2}-$ durasi

(6)

Free Float (FF) adalah penundaan yang masih dapat diberikan pada suatu kegiatan tanpa mengakibatkan penundaan kegiatan-

kegiatan berikutnya.

$$
\begin{aligned}
& \mathrm{FF}=\mathrm{EET}_{2}-\mathrm{EET}_{1}-\text { durasi } \\
& \mathrm{FF}=\mathrm{EET}_{3}-\mathrm{EET}_{2}-\text { durasi }
\end{aligned}
$$

Independent Float (IF) adalah penundaan yang dapat diberikan pada suatu kegiatan tanpa mengakibatkan penundaan kegiatan-kegiatan setelahnya.

$$
\begin{aligned}
& \mathrm{IF}=\mathrm{EET}_{2}-\mathrm{LET}_{1} \text {-durasi } \\
& \mathrm{IF}=\mathrm{EET}_{3}-\mathrm{LET}_{2} \text {-durasi }
\end{aligned}
$$

\section{PENGOLAHAN DATA DAN PEMBAHASAN}

Keadaan yang dihadapi disini adalah adanya perbedaan umur pelaksanaan proyek dengan umur rencana proyek yang telah ditetapkan. Umur rencana proyek biasanya lebih pendek dari pada umur pelaksanaan proyek. Penekanan waktu yang akan dilakukan adalah mempercepat durasi proyek dengan alternatif penambahan jam kerja dan penambahan karyawan untuk diambil mana alternatif yang mengeluarkan biaya seminimal mungkin. Salah satu cara untuk mempercepat durasi proyek dalam istilah asingnya disebut crashing. Jadwal kegiatan proyek dapat dilihat pada gambar 1 .

\section{JADWAL PELAKSANAAN}
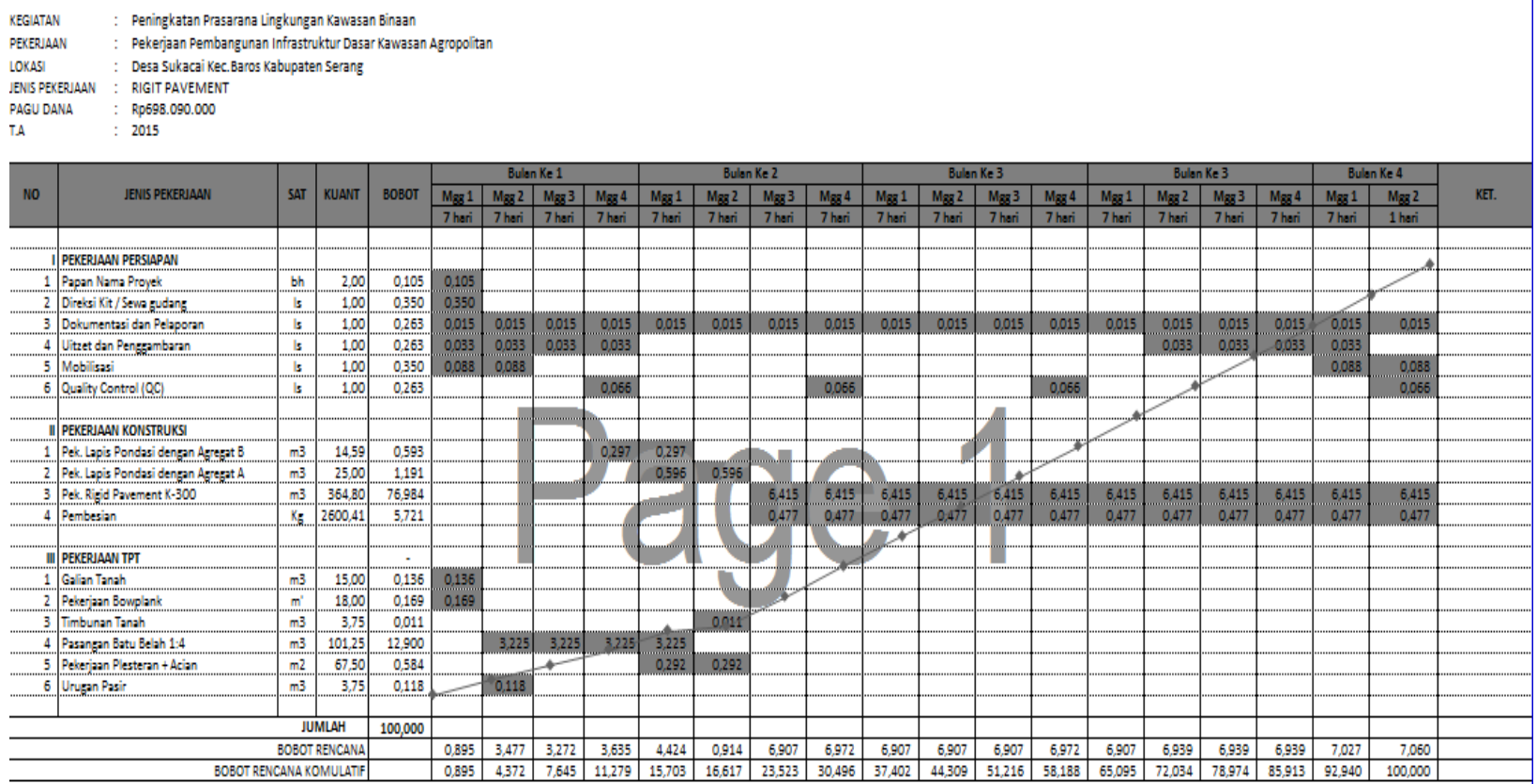

Gambar 6. Jadwal Kegiatan Proyek Pembangunan Infrastruktur Desa 
Dalam jadwal kegiatan proyek pembangunan infrastruktur desa, total waktu yang diperlukan adalah selama 126 yang dimulai dari 8 Juni 2015. Jam kerja normal karyawan proyek 8 jam/hari, dari hari Senin sampai Minggu. Biaya pembangunan sebesar Rp 698.090.00 ditambah biaya untuk karyawan 37 orang. Data biaya karyawan dapat dilihat pada tabel 1. di bawah ini

Tabel 1. Daftar Jumlah dan Upah Karyawan

\begin{tabular}{|c|c|c|c|}
\hline Divisi & $\begin{array}{c}\text { Jumlah } \\
\text { Karyawan }\end{array}$ & $\begin{array}{c}\text { Biaya per } \\
\text { orang @ } \\
\text { Rp90.000 }\end{array}$ & $\begin{array}{c}\text { Biaya Karyawan } \\
126 \text { hari }\end{array}$ \\
\hline Papan Nama & 1 & Rp 90.000 & Rp 11.340 .000 \\
\hline Sewa Gedung & 1 & Rp 90.000 & $\begin{array}{|ll|}\mathrm{Rp} & 11.340 .000 \\
\end{array}$ \\
\hline Dokumentasi dan Pelaporan & 1 & Rp 90.000 & Rp $\quad 11.340 .000$ \\
\hline uitsz dan enggambaran & 1 & Rp 90.000 & Rp 11.340 .000 \\
\hline Mobilisasi & 1 & Rp 90.000 & Rp 11.340 .000 \\
\hline Quality Control & 2 & Rp 180.000 & Rp 22.680 .000 \\
\hline Gali tanah & 2 & Rp 180.000 & Rp 22.680 .000 \\
\hline Pekerjaan Bowplang & 2 & Rp 180.000 & Rp 22.680 .000 \\
\hline Timbun Tanah & 3 & $\operatorname{Rp} 270.000$ & Rp $\quad 34.020 .000$ \\
\hline Pemasangan Batu belah & 4 & Rp 360.000 & Rp 45.360 .000 \\
\hline Pelestran + acian & 2 & Rp 180.000 & Rp 22.680 .000 \\
\hline Urug Pasir & 2 & Rp 180.000 & Rp 22.680 .000 \\
\hline Lapisan Pondasi Agregat B & 3 & $\operatorname{Rp} 270.000$ & Rp 34.020 .000 \\
\hline Lapisan Pondasi Agregat A & 3 & Rp 270.000 & $\mathrm{Rp} 34.020 .000$ \\
\hline Rigit Pavement K-300 & 5 & $\operatorname{Rp} 450.000$ & Rp $\quad 56.700 .000$ \\
\hline Pembesian & 4 & Rp 360.000 & $\begin{array}{ll}\mathrm{Rp} & 45.360 .000\end{array}$ \\
\hline TOTAL & 37 & & Rp 419.580 .000 \\
\hline
\end{tabular}

Jadi, biaya upah karyawan per-hari untuk perbaikan infrastruktrur Desa Sukaci Baros karyawan selama 126 hari yaitu Karyawan

= Biaya Perbaikan infrastruktur + Biaya

$$
\begin{aligned}
& =R p 698.090 .00+R p \quad 419.580 .000 \\
& =R p 1.117 .670 .000
\end{aligned}
$$

Pada metode ini pengolahan data dengan menentukan jadwal (schedule), serta diperoleh berapa lama durasi yang dibutuhkan untuk menyelesaikan proyek tersebut. Selain itu diperoleh lintasan kritis yang berarti waktu paling lama untuk mengerjakan kegiatan proyek tersebut. Proyek dapat dikatakan lebih cepat selesainya jika pengerjaanya kurang dari waktu paling lama di lintasan kritis, sebaliknya jika pengerjaan proyek melebihi waktu paling lama di lintasan kritis maka proyek tersebut mengalami keterlambatan.

Data kegiatan pembangunan infrastuktur dapat dilihat pada tabel 2. di samping ini :
Tabel 2. Durasi Kegiatan pembangunan

\begin{tabular}{|c|c|c|}
\hline Aktivitas & Durasi (Hari) & Pendahulu \\
\hline \multicolumn{3}{|l|}{ Persiapan } \\
\hline 1 Papan Nama & 7 & - \\
\hline 2 Sewa Gedung & 7 & 1 \\
\hline 3 Dokumentasi & 126 & $2 \mathrm{SS}$ \\
\hline 4 uitsz dan enggambaran & 56 & $3 \mathrm{SS}$ \\
\hline 5 Mobilisasi & 28 & $4 \mathrm{SS}$ \\
\hline \begin{tabular}{l|l}
6 & Quality Control \\
\end{tabular} & 28 & 15FS-7d;12FS-7d;15FS-35d;5FF \\
\hline \multicolumn{3}{|l|}{ TPT } \\
\hline 7 Gali tanah & 7 & - \\
\hline 8 Pekerjaan Bowplang & 7 & $7 \mathrm{SS}$ \\
\hline 9 Timbun Tanah & 7 & 10 \\
\hline 10 Pemasangan Batu belah & 28 & 8 \\
\hline 11 Pelestran + acian & 14 & 10FS-21Day \\
\hline 12 Urug Pasir & 7 & 7 \\
\hline \multicolumn{3}{|l|}{ Infrastruktur } \\
\hline 13 Lapisan Pondasi Agregat B & 14 & 10FS,8day \\
\hline 14 Lapisan Pondasi Agregat A & 14 & $13 \mathrm{SS}$ \\
\hline \begin{tabular}{|l|l|}
15 & Rigit Pavement K-300 \\
\end{tabular} & 84 & 14 \\
\hline \begin{tabular}{l|l|}
16 & Pembesian \\
\end{tabular} & 84 & $15 S S$ \\
\hline
\end{tabular}
Proyek Infrastruktur

Secara detail kegiatan pembangunan infrasruktur dapat dilihat pada Gantt chart pada gambar 7 dan jadwal kegiatan proyek pada gambar 8 di samping ini

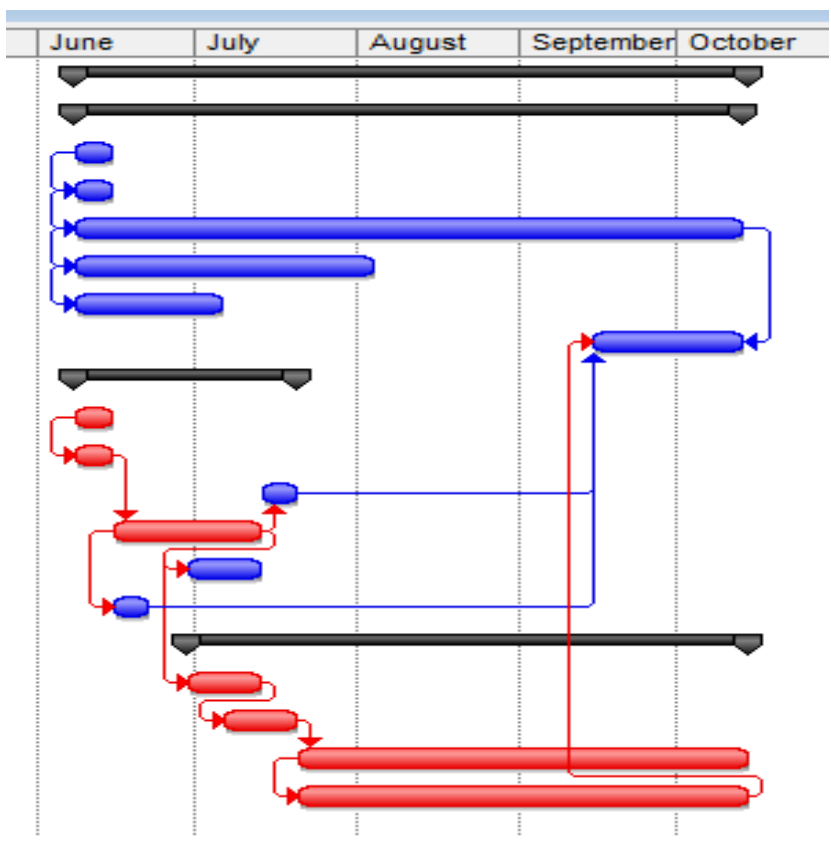

Gambar 7. Gantt Chart Durasi 126 Hari 


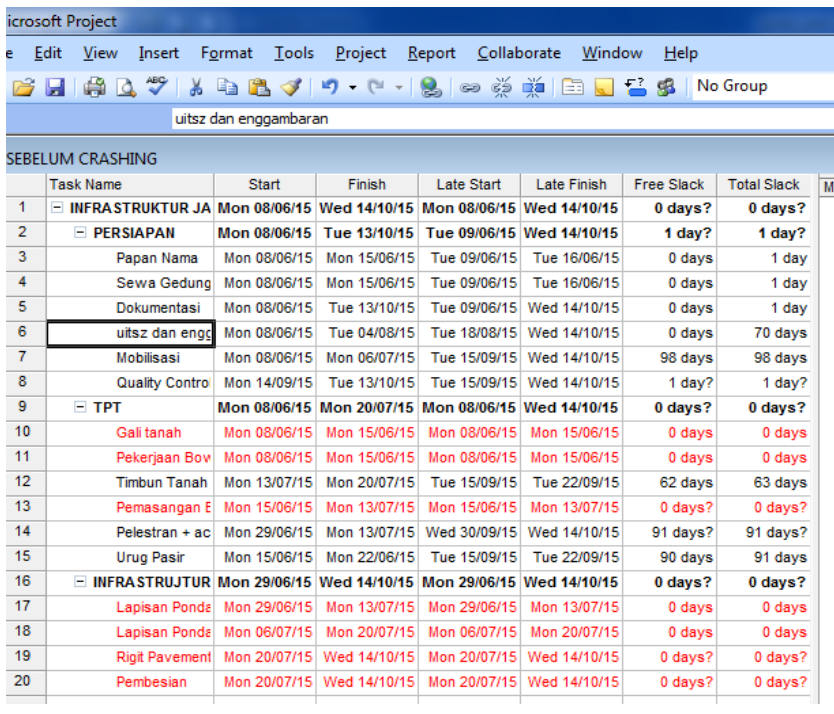

Gambar 8. Schedule Durasi 126 Hari

Dari tabel schedule dapat diketahui jalur kritis pada kegiatan gali tanah, pemasangan bouflang, pemasangan batu belah, perataan agregat $B$, perataan agregat $A$, pekerjaan rigit bavement, dan pembesian. Setelah diketahui jalur kritis maka langkah selanjutnya dilakukan crashing untuk mengoptimalkan waktu pengerjaan proyek.

Crashing dalam pengoptimalan proyek dilakukan dengan 2 cara yaitu penambahan jam lembur pada hari Senin-Rabu dengan masing-masing berdurasi 2 jam dan penambahan karyawan. Penambahan biaya yang diakibatkan penambahan jam kerja pada hari Senin-Rabu dapat dilihat pada tabel 2 dan tabel 3 dibawah ini:

Tabel 3. Biaya Setelah Crashing Untuk Jam Normal Hari Senin - Minggu

\begin{tabular}{|c|c|c|c|c|c|}
\hline Divisi & $\begin{array}{c}\text { Jumlah } \\
\text { Karyawan }\end{array}$ & & $\begin{array}{l}\text { org = } \\
0 / \text { jam }\end{array}$ & & 92 hari \\
\hline Papan Nama & 1 & $\mathrm{Rp}$ & 90.000 & $\mathrm{Rp}$ & 8.280 .000 \\
\hline Sewa Gedung & 1 & $\mathrm{Rp}$ & 90.000 & $\mathrm{Rp}$ & 8.280 .000 \\
\hline Dokumentasi dan Pelaporan & 1 & $\mathrm{Rp}$ & 90.000 & $\mathrm{Rp}$ & 8.280 .000 \\
\hline uitsz dan enggambaran & 1 & $\mathrm{Rp}$ & 90.000 & $\mathrm{Rp}$ & 8.280 .000 \\
\hline Mobilisasi & 1 & $\mathrm{Rp}$ & 90.000 & $\mathrm{Rp}$ & 8.280 .000 \\
\hline Quality Control & 2 & $\mathrm{Rp}$ & 180.000 & $\mathrm{Rp}$ & 16.560 .000 \\
\hline Gali tanah & 2 & $\mathrm{Rp}$ & 180.000 & $\mathrm{Rp}$ & 16.560 .000 \\
\hline Pekerjaan Bowplang & 2 & $\mathrm{Rp}$ & 180.000 & $\mathrm{Rp}$ & 16.560 .000 \\
\hline Timbun Tanah & 3 & $\mathrm{Rp}$ & 270.000 & $\mathrm{Rp}$ & 24.840 .000 \\
\hline Pemasangan Batu belah & 4 & $\mathrm{Rp}$ & 360.000 & Rp & 33.120 .000 \\
\hline Pelestran + acian & 2 & $\mathrm{Rp}$ & 180.000 & $\mathrm{Rp}$ & 16.560 .000 \\
\hline Urug Pasir & 2 & $\mathrm{Rp}$ & 180.000 & $\mathrm{Rp}$ & 16.560 .000 \\
\hline Lapisan Pondasi Agregat B & 3 & $\mathrm{Rp}$ & 270.000 & $\mathrm{Rp}$ & 24.840 .000 \\
\hline Lapisan Pondasi Agregat A & 3 & $\mathrm{Rp}$ & 270.000 & $\mathrm{Rp}$ & 24.840 .000 \\
\hline Rigit Pavement K-300 & 5 & $\mathrm{Rp}$ & 450.000 & Rp & 41.400 .000 \\
\hline Pembesian & 4 & $\mathrm{Rp}$ & 360.000 & $\mathrm{Rp}$ & 33.120 .000 \\
\hline \multicolumn{4}{|c|}{ TOTAL } & Rp & 306.360.000 \\
\hline
\end{tabular}

Tabel 4. Biaya Setelah Crashing Untuk Jam Lembur Senin - Rabu 2 Jam

\begin{tabular}{|c|c|c|c|c|c|}
\hline Divisi & \begin{tabular}{|l} 
Jumbhh \\
Karaxaxan
\end{tabular} & 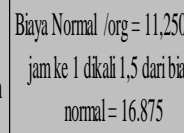 & ibijaya & 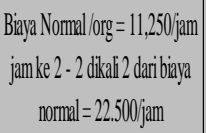 & 39 hari (2jam) \\
\hline Papan Nama & 1 & Rp & $16.875 \mathrm{kp}$ & 22500 & Rp 894.375 \\
\hline Sewa Gedung & 1 & Rp & $16.875 \mathrm{RP}$ & 22500 & Rp 894.375 \\
\hline Dokumentasidian Peaporara & 1 & Rp & $16.875 \mathrm{Rp}$ & 22500 & Rp $\quad 894.375$ \\
\hline uiszzdan engegambaran & 1 & Rp & $16.875 \mathrm{Rp}$ & 22500 & Rp 894.375 \\
\hline \begin{tabular}{|l|} 
Mobilizasi \\
\end{tabular} & 1 & $\mathrm{Rp}$ & $16.875 \mathrm{Rp}$ & 22500 & Rp $\quad 894.375$ \\
\hline Quality Control & 2 & Rp & $33.750 \mathrm{RP}$ & 45.000 & Rp 1.788 .750 \\
\hline Gail tanah & 2 & Rp & $33.750 \mathrm{Rp}$ & 45.000 & $\begin{array}{l}\text { Rp } 1.788 .750 \\
\end{array}$ \\
\hline Pekerjanan Bovplang & 2 & $\mathrm{Rp}$ & $33.750 \mathrm{R}$ & 45.000 & Rp 1.788 .750 \\
\hline TrmbunTanahh & 3 & Rp & $50.625 \mathrm{R}$ & 67.500 & Rp 2.683.125 \\
\hline Pemansangan Batubleah & 4 & $\mathrm{Rp}$ & $67.500 \mathrm{Rp}$ & 90.000 & Rp 3.577 .500 \\
\hline Peestran + acian & 2 & Rp & $33.750 \mathrm{Rp}$ & 45.000 & Rp 1.788 .750 \\
\hline UnugPasir & 2 & $\mathrm{Rp}$ & $337.750 \mathrm{Rp}$ & 45.000 & Rp 1.788 .750 \\
\hline Lapisan Pondasi Agregat B & 3 & $\mathrm{Rp}$ & $50.625 \mathrm{Rp}$ & 67.500 & Rp 2.683.125 \\
\hline Lapisam Pondasi Agregat A & 3 & $\mathrm{Rp}$ & $50.625 \mathrm{Rp}$ & 67.500 & Rp 2.683.125 \\
\hline Rigit Ravenent K-300 & 5 & Rp & $84.375 \mathrm{Rp}$ & 112.500 & Rp 4.471.875 \\
\hline Pembesian & 4 & Rp & $67.500 \mathrm{Rp}$ & 90.000 & Rp 3.577.500 \\
\hline \multicolumn{5}{|c|}{ TOTAL } & $\begin{array}{ll}\text { Rp 33.091.875 } \\
\end{array}$ \\
\hline
\end{tabular}

Berdasarkan tabel di atas maka biaya setelah Crashing dengan penambahan jam kerja lembur hari Senin- Rabu selama 2 jam yaitu :

= Biaya Pembangunan + Biaya Karyawan

$=R p$ 698.090.00 $+(R p$ 306.360.000 $+R p$ 33.091.875)

$=\operatorname{Rp} 1.037 .541 .875$

Crashing yang kedua adalah melakukan penambahan tenaga kerja. Penambahan tenaga kerja dilakukan pada jalur kritis yang terjadi seperti pada tabel 5 dan biaya akibat penambahan tenaga kerja dapat dilihat pada tabel 6 di bawah ini:

Tabel 7. Penambahan Tenaga Kerja Pada Kegiatan Lintas Kritis

\begin{tabular}{|c|l|c|c|c|}
\hline No & Aktivitas & Jumlah Karyawan Awal & Penambahan Karyawan & Jumlah \\
\hline 10 & Gali Tanah & 3 & - & 3 \\
\hline 11 & Pemas.Boutlang & 4 & - & 4 \\
\hline 13 & Pemasangan Batu Belah & 4 & 2 & 6 \\
\hline 17 & Agregat B & 3 & 1 & 4 \\
\hline 18 & Agregat A & 3 & - & 3 \\
\hline 19 & Pek.Bavement & 5 & 2 & 7 \\
\hline 20 & Pembesian & 4 & 2 & 6 \\
\hline
\end{tabular}


Tabel 8. Biaya Setelah Crashing Untuk Penambahan Tenaga Kerja

\begin{tabular}{|c|c|c|c|c|c|c|}
\hline Divisi & Jumlah Karyawan Awal & $\begin{array}{l}\text { Penambahan } \\
\text { Karyawan }\end{array}$ & Durasi & Jumlah Karyawan & Biaya/org $=$ Rp 90,000/Hari & 92 HARI \\
\hline Papan Nama & 1 & 0 & 7 & 1 & 90.000 & Rp $\quad 8.280 .000$ \\
\hline Sewa Gedung & 1 & 0 & 7 & 1 & 90,000 & $\operatorname{Rp} \quad 8.280 .000$ \\
\hline Dokumentasidan Pelaporan & 1 & 0 & 72 & 1 & 90.000 & $\operatorname{Rp} \quad 8.280 .000$ \\
\hline uitsz dan engogambaran & 1 & 0 & 56 & 1 & 90.000 & $\operatorname{Rp} \quad 8.280 .000$ \\
\hline Mobilisasi & 1 & 0 & 28 & 1 & 90,000 & $\operatorname{Rp} \quad 8.280 .000$ \\
\hline Quality Control & 2 & 0 & 28 & 2 & 180.000 & Rp 16.560 .000 \\
\hline Gali tanah & 2 & 0 & 7 & 2 & 180.000 & Rp 16.560 .000 \\
\hline Pekerjaan Bowplang & 2 & 0 & 7 & 2 & 180.000 & Rp 16.560 .000 \\
\hline Timbun Tanah & 3 & 0 & 7 & 3 & 270.000 & $\operatorname{Rp} 24.840 .000$ \\
\hline Pemasangan Batu belah & 4 & 2 & 20 & 6 & 540.000 & $\operatorname{Rp} 49.680 .000$ \\
\hline Pelestran + acian & 2 & 0 & 14 & 2 & 180.000 & $\operatorname{Rp} 16.560 .000$ \\
\hline Urug Pasii & 2 & 0 & 7 & 2 & 180.000 & $\operatorname{Rp} 16.560 .000$ \\
\hline Lapisan Pondasi Agregat B & 3 & 1 & 12 & 4 & 360.000 & $\operatorname{Rp} 33.120 .000$ \\
\hline Lapisan Pondasi Agregat A & 3 & 0 & 14 & 3 & 270.000 & Rp 24.840.000 \\
\hline Rigit Pavement K-300 & 5 & 2 & 60 & 7 & 630,000 & $\operatorname{Rp} 57.960 .000$ \\
\hline Pembesian & 4 & 2 & 60 & 6 & 540.000 & $\operatorname{Rp} 49.680 .000$ \\
\hline \multicolumn{5}{|c|}{ Total } & & $\operatorname{Rp} 364.320 .000$ \\
\hline
\end{tabular}

Jadi, biaya setelah Crashing dengan penambahan tenaga kerja yaitu :

$=$ Biaya Perbaikan infrastruktur + Biaya Crashing

Penambahan Karyawan

$=\operatorname{Rp} 698.090 .00+\operatorname{Rp} 364.320 .000$

$=$ Rp. 1.062 .410 .000

Dari dua alternatif crashing yang dilakukan dapat diperoleh hasil yaitu terjadi percepatan durasi proyek dari 126 hari menjadi 92 hari dengan biaya $\mathrm{Rp}$ 1.037.541.875 untuk penambahan lembur dan Rp. 1.062.410.000 untuk penambahan tenaga kerja.

Dari crashing yang dilakukan maka diambil keputusan menggunakan penambahan jam lembur dikarenakan biaya yang dikeluarkan lebih sedikit. Tambahan waktu kerja ini mampu menghemat pengerjaan proyek dari 126 hari menjadi 92 hari dengan keuntungan Rp. 80.128.125 dibandingkan dengan pengerjaan rencana awal.

Hasil ini sesuai yang dilakukan oleh Priyo \& Aulia (2015) dan Anggraeni \& Hartono (2017) yang mendapatkan penambahan waktu lembur lebih efesien dibandingkan dengan penambahan tenaga kerja. Hal ini berbeda dengan penelitian yang dilakukan oleh Hidayat (2016) dan Lestari (2016) yang mendapatkan hasil penambahan tenaga kerja lebih murah jika dibandingkan dengan penambahan jam lembur. Perbedaan ini bisa disebabkan lamanya proyek serta penentuan jumlah jam lembur perhari. Semakin banyak durasi lembur yang ditambahkan maka semakin besar pula biaya yang harus dikeluarkan.

\section{KESIMPULAN}

Penggunaan Critical Path Method (CPM) dapat diketemukan pekerjaan yang berada dilintasan kritis diantaranya Gali Tanah, Pemasangan Boflang, Pemasangan Batu Belah, Perataan Agregat B, Perataan Agregat A, Pekerjaan Rigit Bavement, dan Pembesian. Penambahan waktu kerja dihari Senin sampai Rabu dengan tiap durasi 2 jam mampu menghemat waktu pengerjaan proyek dari 126 hari menjadi 92 hari. Penambahan jam kerja mendapatkan selisih Rp 80.128.125 dari biaya normal.

\section{DAFTAR PUSTAKA}

Anggraeni, E. R., \& Hartono, W. (2017). Analisis Percepatan Proyek Menggunakan Metode Crashing Dengan Penambahan Tenaga Kerja dan Shift Kerja (Studi Kasus: Proyek Pembangunan Hotel Grand Kesha, Yogyakarta). Matriks Teknik Sipil, 5(2), 605-614.

Aribowo, D., Fatkhurokhman, M., \& Hamid, M. A. (2016). Sistem Perencanaan Ulang dan Pengendalian Produksi Heat Exchanger Menggunakan Metode Critical Path. In SENTIA (Vol. 8, pp. 1-5). Malang: Politeknik Negeri Malang.

Handayani, E., \& Dedy Iskandar. (2015). Penerapan Manajemen Waktu Menggunakan Network Planning (CPM) pada Proyek Kontruksi Jalan (Studi Kasus Peningkatan Jalan Sp. Berembang-Sp Jambi Kecil). Jurnal IImiah Universitas Batanghari Jambi, 15(1), 22-28.

Hardiyanta, I. D. M. Y. (2015). Optimalisasi Waktu dan Biaya Pelaksanaan Pekerjaan dengan Metode Least Cost Analysis. Disertasi. Universitas Udayana, Bali.

Hidayat, A. K. (2016). Analisis Biaya dan Waktu Proyek Kontruksi Dengan Penambahan Jam kerja (Lembur) Dibandingkan Penambahan Tenaga Kerja Menggunakan Metode Time Cost Trade Off (Studi Kasus: Pekerjaan Pembangunan Hotel Cordela Yogyakarta Lantai 4-Lantai Atap). Skripsi. Fakultas Teknik Universitas Muhammadiyah Yogyakarta. 
Husen, A. (2011). Manajemen Proyek: Perencanaan, Penjadwalan, dan Pengendalian Proyek. Yogyakarta: Andi.

Lestari, D. (2016). Analisis Biaya dan Waktu Proyek Kontruksi Dengan Penambahan Jam kerja (Lembur) Dibandingkan Penambahan Tenaga Kerja Menggunakan Metode Time Cost Trade Off (Studi Kasus: Pekerjaan Peningkatan Ruas Jalan Siluk-Kretek Sta $0+000$ sampai STA 6+ 773, 3 Kab. Bantul, Provinsi Daerah Istimewa Yogyakarta). Skripsi. Fakultas Teknik Universitas Muhammadiyah Yogyakarta.

Munang, A., Faizal, RM., \& Mansur, A. (2016). Evaluasi dan Perencanaan Mitigasi Resiko Proyek Pembangunan Jalur Ganda Kereta Api Semarang Bojonegoro. Teknoin, 22(2), 1-10.

Priyo, M., \& Aulia, M. R. (2015). Aplikasi Metode Time Cost Trade Off Pada Proyek Konstruksi : Studi Kasus Proyek Pembangunan Gedung Indonesia. Jurnal IImiah Semesta Teknika, 18(1), 30-43.

Rosanti, N., Setiawan, E., \& Ayuningtyas, A. (2016). Penggunaan Metode Jalur Kritis Pada Manajemen Proyek (Studi Kasus: PT. Trend Communication International). Jurnal Teknologi, 8(1), 1-8.

Saputra, D. A., Satria, E., \& Pandy, G. A. (2016). Optimalisasi Proses Perakitan Pesawat Tanpa Awak Dengan Metode Crtical Path Methods (CPM). Jurnal Oprimasi Sistem Industri, 15(1), 87-92. 